\title{
Research Analysis Regarding the Competiveness of China's Automobile Industry Clusters
}

-Focusing on the clusters in China's northeastern region

\author{
Hyung-Geun Kim*
}

\begin{abstract}
China is currently developing and promoting an industrial cluster policy at the government level. By enacting the 'Opinion on promoting industrial cluster development', China is supporting the development of industrial clusters. Building an industrial cluster is done by using a single factor but requires many additional factors like regional characteristics, competitiveness factors are also diversified. To evaluate the competitiveness of the Chinese automobile industry cluster, a competitiveness element index should be developed and a competitiveness evaluation method is needed to evaluate the importance of each element. To accomplish this objective, this research applied the analytic hierarchy process (AHP) and focused on the importance of the competitiveness elements.

This research investigated the character is tics regarding cases of clusters and also analyzed the competitiveness of the Changchun automobile cluster located in northeastern China. The purpose of this research is to help Korean enterprises who enter China in the hopes that Korea will emerge as a top automobile production country.
\end{abstract}

Keywords: automobile cluster, competitive, northeast China, AHP analysis

Submission Date: 4/18/2011 Revision Date: 05/18/2011 Acceptance Date: 05/18/2011

* Research Professor, Jungseok Research Institute, Inha University, 253 Yonghyun-Dong, Nam-Gu, Incheon, 402-751, Korea, e-mail:wellroot@inha.ac.kr 


\section{Introduction}

With global competition continuing to grow, each country is trying to make its region as competitive as possible. One of the current ways that countries are doing this is through building clusters. We live in an era in which the opening of markets and international competition are inevitable. In this rapid changing competitive environment; the only way for companies to sustain continuous growth and permanence is to secure a competitive advantage. Since the subprime mortgage crisis which occurred in the United States in 2008, all countries through out the world have been working hard to save their economies. Because of this situation, manufacturing companies are heavily in fluenced by economic, environmental, high-technology, and green growth factors which are all facing fierce competition. Therefore, manufacturing companies throughout the world are establishing industrial complexes in an attempt to increase their domestic and corporate competitiveness.

An industrial complex is generally a planned development site which participates in profit production activities related to enterprises, production sites for factories, and additional facilities which are provided at the locations. Industrial complexes are often divided into two types - big companies as well as related subcontracted companies and companies which have no interrelationships. However, there is generally a production concentration in either case. Quality price competitiveness is needed in order for economic development to occur and the industrial cluster aides in overcoming the limits of an industrial complex by helping to concentrate production.

Full-scale discussion of industrial complexes in Korea is said to have started in 2000 when the countries regional industrial policy kicked into high gear. Industrial complexes began turning into industrial clusters under the so called 'industry complex cluster policy', which began in 2004. This does not mean that there was not any cluster activity in the previous industrial development plans. The origins of the Korean industrial cluster policy actually go all the way back to the Building Industrial Development Area Policy in the 1960 s, and more fundamentally to the 'naturally grown group status'of the traditional industry. Originally, the industry cluster was defined as a situation where companies enjoy the 'advantage of interaction' between strategically placed companies. These groups were set up for the 'advantage of agglomeration' based on regional resources. An analogy would be grape buds making a bunch (cluster) of grapes.

China is also currently promoting and developing an industrial cluster policy at the government level. By enacting the 'Opinion on promoting industrial cluster development', China is supporting the development of industrial clusters. 1)

It is important to note that building an industrial cluster is not done by using a single 
factor, but requires many factors such as regional characteristics and competitiveness factors are also diversified.

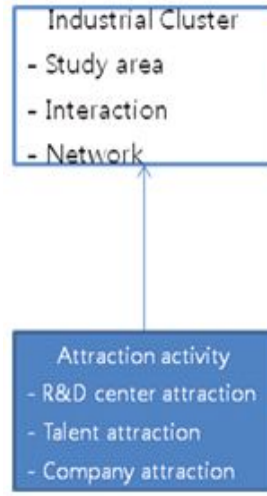

- Talent attraction
- Company attraction

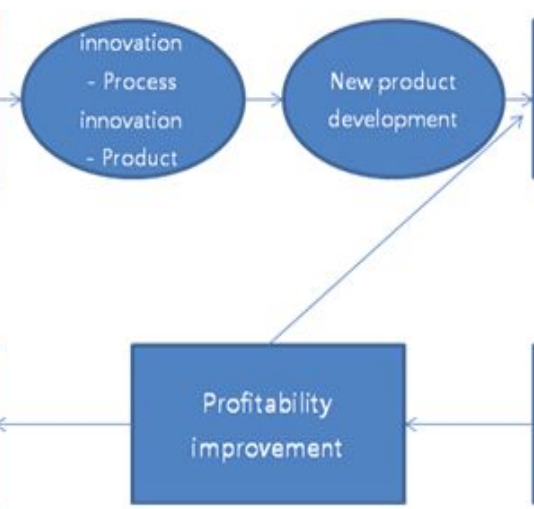

Figure 1.

The macroscopic cycle structure of an industrial cluster

This research will investigate the positive characteristics of clusters and also analyze the competitiveness of the Changchun automobile cluster which is located in northeastern China. The purpose of this research is to help Korean enterprises entering China in the hopes that Korea will emerge as a top automobile production country.

\section{Theoretical review of industrial clusters}

\subsection{Theoretical review}

A theoretical review of clusters is closely related to innovation. In a situation which emphasizes the importance of innovation as a source of industry and company competitiveness, innovation includes not only technology innovation, but innovation in other areas such as business administration, marketing, etc. (OECD, 1992)

The term cluster is described by Porter(1990), who proposed a diamond model to analyze clusters as a common characteristic of competitive countries. He insisted that the competitiveness of countries is often led by a small regional cluster(Kim eunjeong, 2004).

It is generally understood that a cluster is a connected group with a similar purpose

1) http://www.sdpc.gov.cn/zcfb/zcfbtz/2007tongzhi/t20071205_176934.htm 
and complementary enterprises and related institutions. The regional scale of the cluster varies from a single city or state to an entire country or network of neighboring countries(Kim, gyeongmuk, Kim yeonseong, 2001). It is difficult to find a common definition of a cluster because the concept varies depending on the researcher and sector. Although the concept of a cluster is not defined firmly, it is clear that a cluster is aimed at the high-tech industry, which differs from traditional industries, by creating economies of scale and scope in specific regions rather than through mass production, and by emphasizing continuous innovation through group studies. So a theory of the cluster needs to encompass the total phenomenon and apprehend the core factors (Kim Jeong Ho, 2004; Lee eunseok, 2005).

\section{Table 1.}

Definitions of Cluster

\begin{tabular}{|c|c|}
\hline Researcher & Definition \\
\hline Enright(1996) & A group of closely connected enterprises \\
\hline $\begin{array}{c}\text { Swann\&Prevezer } \\
(1996)\end{array}$ & A group of enterprises based on one regional area in one industry \\
\hline Resenfeld(1997) & $\begin{array}{l}\text { A concentration of enterprises which can create synergy effects because of } \\
\text { regional accessibility and interdependency, although the scale is not } \\
\text { remarkable. }\end{array}$ \\
\hline Feser(1998) & $\begin{array}{l}\text { Supporting and transferring a system or organization in which } \\
\text { competitiveness is pursued through connections of companies supporting } \\
\text { each other in a related industry. }\end{array}$ \\
\hline Porter(1998a) & $\begin{array}{l}\text { A network between production enterprises related to creating a production } \\
\text { chain that adds value to component and material supply enterprises and } \\
\text { final consumer users. }\end{array}$ \\
\hline $\begin{array}{l}\text { Swann\&Prevezer } \\
\text { (1996) }\end{array}$ & A big group of enterprises in a related industry in a specific region. \\
\hline $\begin{array}{l}\text { Roelandt\& } \\
\quad \text { Den } \\
\text { Hertag(1999) }\end{array}$ & $\begin{array}{l}\text { A network of interdependent enterprises that includes suppliers, producers } \\
\text { and related institutions in a production network creating added value. }\end{array}$ \\
\hline OECD(1999) & $\begin{array}{l}\text { An innovation cluster contains organizational knowledge, such as universities, } \\
\text { public research institutions, construction companies, knowledge-based service } \\
\text { companies, brokers, etc. A driving force in clusters is technology innovation, } \\
\text { creating added value by expanding network externalities through creation and } \\
\text { the spread of technology. }\end{array}$ \\
\hline
\end{tabular}




\begin{tabular}{|c|c|}
\hline Researcher & Definition \\
\hline $\begin{array}{l}\text { Simmie\&Sennett } \\
\text { (1999) }\end{array}$ & $\begin{array}{l}\text { A group of interrelated industrial and service provider enterprises working } \\
\text { in the same market condition. }\end{array}$ \\
\hline DETR(1999) & $\begin{array}{l}\text { A regional concentration of interconnected enterprises including specialized } \\
\text { providers, service providers, and related organizations and institutions. }\end{array}$ \\
\hline $\begin{array}{l}\text { Van den Berg } \\
\text { and others(2001) }\end{array}$ & $\begin{array}{l}\text { A regional network of organizations closely related to the regional network } \\
\text { and closely connected to organizations specializing in the production process } \\
\text { through services and product innovation. }\end{array}$ \\
\hline $\begin{array}{c}\text { Bock } \\
\operatorname{DeukGyu}(2003)\end{array}$ & $\begin{array}{l}\text { A certain region showing synergy through interaction of networks of } \\
\text { related enterprises and institutions supporting service enterprises. }\end{array}$ \\
\hline $\begin{array}{l}\text { Ministry of } \\
\text { Commerce, } \\
\text { Industry and } \\
\text { Energy } \\
(2003)\end{array}$ & $\begin{array}{l}\text { A regional unit showing synergy effects in business development, } \\
\text { technology development, component procurement, human and information } \\
\text { exchange through networks, and interaction of enterprises, universities, and } \\
\text { research institutions in a specific region. }\end{array}$ \\
\hline $\begin{array}{l}\text { Ministry of } \\
\text { Agriculture and } \\
\text { Forestry } \\
\text { (2004) }\end{array}$ & $\begin{array}{l}\text { An organization concentrating on creating industry-university-institution } \\
\text {-administration networks related to agricultural production, distribution, } \\
\text { manufacturing, and storage in certain regions and providing synergy effects } \\
\text { for business opportunity expansion and regional agriculture innovation. }\end{array}$ \\
\hline $\begin{array}{c}\operatorname{Kim} \\
\text { JeongHo(2004) }\end{array}$ & $\begin{array}{l}\text { An organization concentrating on creating industry - university - institution } \\
\text { - administration networks related to agricultural production, distribution, } \\
\text { and manufacturing in certain regions and providing synergy effects through } \\
\text { competition and cooperation. }\end{array}$ \\
\hline $\begin{array}{l}\text { ChooMan } \\
\text { Ho(2007) }\end{array}$ & $\begin{array}{l}\text { An organization providing synergy effects from universities, institutions, } \\
\text { big companies, small venture companies, logistics, finance, and consumers } \\
\text { through information, knowledge sharing, etc. }\end{array}$ \\
\hline
\end{tabular}

Source: Adapted from Choi Sang Ho(2005), Kim JeongHo(2004), Choo Man Ho(2007).

A cluster begins with a geographical concentration. Enterprises and institutions gather in a certain area, and productive relationships are formed based on technology and innovation. In a traditional regional cluster, low wage labor and an agglomeration of components and related industries were very important factors. However, in a high-tech cluster, sector and functional characteristics become more important. In other words, a technology industry cluster is characterized by sub-clusters linked by a network or spatial area. So, regional exclusiveness ${ }^{2}$, which was a characteristic of a traditional cluster, is substituted by functional proximity in a high-tech industrial cluster. 
In the case of the Chinese, who are pursuing high growth through an industrial cluster within an export industry at the center and are highly dependent on foreign capital and technology, there could be possible implications to the existing cluster theory. Especially because of the distinctiveness of the Chinese economic system, which is shifting into a market economy from the socialist planned economy, it is expected that not only the primary actors of regional innovation will be very different from capitalist countries, but that the network for mation will be different because of the socialist system. This research is important because of the expansion of existing Regional Innovation System theories (Nelson, 1993:507) ${ }^{3}$ ). Although some researchers have previously analyzed the innovation system of socialist planned economies, these analyses were in complete. For example, the fact that these countries have different starting conditions in comparison to developed countries and the development possibility of principle distributing jobs by a country into substituting system construction for technological innovation.

Initial research on the Chinese Country Innovation System by IDRC(International Development Research Centre, 1997) analyzed actors, policy, and institutions of the system and the limits and problems of the organization and policy. However, there was not a systematic analysis of the system construction, dynamics, and innovation performance. Also by analyzing the innovation actors' activity forms and policy functions within a Western research framework, the special status of the socialist market economy system was ignored. Generally, a planned economy does not have to organize actors for innovation artificially. Actors who will do the necessary work already are part of the plan. However, the possible problem is whether proper incentive structures are in place to attract actors and support the performance and economic capabilities of the actors. (Carlsson and Eliasoon, 1994). For example, in a capitalist market economy, the object of innovation is the company because capitalism understands innovation as a development of new technology and application (Nelson, 1993). But in a socialist planned economy, this precondition is hard to meet. The planned economy organizes innovation actors into a special organization which operates like the government, and its functional activity zone is strictly restricted (McDonald, 1990). Therefore, all research (carrying out creative or innovative activity) is performed in a laboratory under governmental control and supervision; the company or factory is only used for production; technology or innovation is spread through a governmental distribution organization. Under a centralized planned economy, the company or factory has no right or incentive to propel innovation and change, and the laboratory has no right to perform production activities. So interaction between them should

2) Bock DeukGyu, "Review of cluster concept", Trendsand Prospect, Vol. 57, 2002.

3) R. Nelson (1993) acknowledged that in the case of China and Soviet Russia, the innovation process and performance of actors were different from Western capitalism countries. 
not be expected, and only internal organizational resources can be distributed or transferred when ordered by the central government (Naughton, 1990).

Because of the diversity and characteristics of innovation, creating innovation requires complicated feedback mechanisms and interactive relationships of various economic actors in the areas of science, technology, production, policy, and demand analysis. The importance of interaction between economic actors in creating innovation is emphasized within the innovation mechanism analysis based on the continuous production development cycle (Padmore and Gibson, 1998).

In the 1990s, not only the static effectiveness of cost reduction and public use of production equipment, but also the dynamic effectiveness of social capital ${ }^{4}$ ), learning regions $^{5)}$, and institutional thickness ${ }^{6}$, which can create innovation energy, was being emphasized.

Porter(1998) saw a very important opportunity for expanding the importance of clusters by proposing the diamond model, which emphasizes and analyzes clusters as a source of a country's competitiveness. A combination of the industry cluster theory and innovation system theory was developed as regional innovation system theory embraced regional industry, innovation infrastructure, supporting systems, and promoting systems. The regional innovation system theory concentrated on how to improve central and innovation abilities.

There have been several domestic researchers who have focused on clusters, but most of them have covered secondary or tertiary industries. Kim, byeongtae(2005) said that the growth of clusters would be possible only when research and development competence and governmental policy supported the clusters. Lee, yeongsik(2006) insisted that theoretical discussion regarding industrial clusters is deficient, and that there is not enough experiential evidence to currently prove the expected effects from clusters. Chu, manho(2007) said clusters would apply to new environments and contribute to creating regional and industrial competitiveness.

4) Social capital was analyzed by Cooke and Heidenreich (1998), and they emphasized the sharing of resources and information based on trust between members as a growth element.

5) Learning region is a concept emphasizing interaction and collective learning between economic actors and workers in an industrial complex.

6) Institutional thickness, a concept developed by Capello (1999), emphasizes that the existence of various related organizations, community customs, and common recognition is important for industry development as a general characteristic. 


\subsection{Research method}

To evaluate the competitiveness of the Chinese automobile industry cluster, a competitiveness element index should be developed and a competitiveness evaluation method will be needed to evaluate the importance of each element. To accomplish this objective, this research has applied the analytic hierarchy process (AHP) and draws out the importance of the competitiveness elements. AHP is one of the multiple criteria decision methods developed by Thomas L. Saaty in 1976. AHP divides a single problem into a few hierarchies, makes pairs of elements contained in each hierarchy, and then evaluates the relative importance of the elements with regards to the high risk evaluation standard. The local weight in one hierarchy using the evaluation standard of high rank can be calculated by the eigen vector of square matrix, with the result of a dual comparison. Generally, about

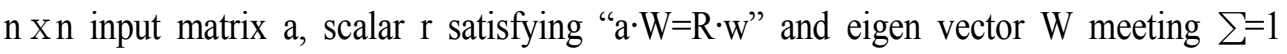
becomes the local weight. In other words, the AHP does not require a measured optimum relative weight for each standard under a multiple criteria decision environment, but helps draw systematic and rational results for the total objective through pair-wise comparisons by standards. Through this process, AHP calculates the consistency ratio (CR) and evaluates inconsistencies that can occur in comparing and evaluating different evaluation standards. As a result, the process improves the reliability of the evaluation results.7) $\mathrm{CR}$ becomes 0 when the consistency is perfect, and CR has a value of more than 0 when the consistency worsens. According to statistical theoretical inspection, the threshold which assures reliability of the consistency index(CI) is 0.1 and the threshold assuring reliability of CR is $10 \%$.

7) The consistency of the AHP model could be inspected by using CR, an index of reliability for specialist knowledge. Consistency informs that when object is $\mathrm{x}$ times more important than and is y times more important than, is xxy times more important than. The mathematical interpretation of maintaining consistency determines the consistency of matrix A as scale (CI, consistency index) where can know how much the biggest value of relative importance of $i$ to $j$ in pair-wise comparison matrix $A=(), i, j=1,2,3, \cdots n$ () is approached to $n$ through the fact that small changes in the matrix element did not have much effect on the eigenvalue. Meanwhile, to inspect constancy, CRdividing CI by RI (random index) is used in AHP. 


\section{Policy and status of the Chinese automobile industrial cluster}

\subsection{Policy promoting status of Chinese local government}

In the early 1980s, China established special economic zones, economic-technological development zones, bonded areas, foreign trade zones and others areas to attract foreign capital investment as part of its economic reform and opening up to the West. Industrial complexes, like high-technology development area and Institutions of Science and Technology, were established by the HuoJu Plan8) as part of the scientific technology policy during the 1990s. With increased attention to clusters in the late 1990's throughout the world, China began to pay attention to clusters as a part of discussions within the government and academia. It also supported and promoted the opening of national growth hubs, and local government began actively supporting and improving regional competitiveness.

Recently, the creation of clusters has become an initiative of the local government. Ripple effects from the industrial concentrations which were built in the Guangdong province, Zhejiang province, and other provinces have spurred output and regional economic growth and aroused the interest of local governments. During the early reform period, local governments did not participate in the industrial concentrations or clusters. However, recent public support has led to the building of clusters by local governments. Each regional local government has developed a cluster policy and is now actively working to promote on-site surveys, holding international seminars, and other measures to build clusters.

\subsection{Status of Chinese automobile industrial cluster}

Since the 1980s, China's economy has grown rapidly. Demand for automobiles has increased along with the increase in per capita gross domestic product (GDP), increased household income, and decreased automobile prices. Spontaneously, the combination of government support for the automobile and machine work industries, as well as offering land for production facilities has became a driving force in the development of the Chinese automobile industry.

8) The framework was to promote restructuring in order to attract many research institutions and military enterprises in the high-technology development area and transfer high-tech research results to traditional industry. It was also intended to expand foreign capital and reinforce cooperation between the coast and interior high-technology development areas. 
The automobile cluster should be examined from both the microscopic and macroscopic levels. A cluster is successfully formed when macroscopic aspects, such as supply and market demand, industrial policy, the regional industry, specialized social division of labor, technology innovation, industrial competition, industrial structure, and microscopic as pects such as cost reduction and brand development are all in harmony.

The Chinese automobile industrial clusters are located in the Chang Jiang Delta, Zhu Jiang Delta, Hwan Bohai Delta, and other regions. These Chinese automobile industrial clusters have been formed and developed by each region.

\subsection{Outline of the Northeast region's automobile industrial cluster}

Heilongjiang Province, Jilin Province, and Liaoning Province - these three provinces make up the Northeast region. The FAW group, one of the three Chinese automobile groups, in Changchun, Jilin Provinceis the location of the Zhongxing Automobile Company, which produces components and is a major hub for Chinese automobile technology, is located in Haerbin, Heilongjiang Province. Huachen BMW Automotive, which is joint-venture between Huachen Automobile and Germany's BMW. Jinbei automobile is located in the Shenyang, Liaoning Province.

In the Jilin Province, Jilin University's College of Automotive Engineering is a core institution for developing workers and providing a research base for the Chinese automobile industry. The college promotes important industrial projects like steel, energy, chemical engineering, medium machinery, shipbuilding, and airplanes and is seen to have great potential for automobile industry development.

There are two major characteristics of the Northeast region's automobile industry cluster: it is organized around a group of major companies formed by large-scale investment by the government, and there are related small businesses, research institutions, and brokerages.

Table 2.

Status of the Chinese automobile industrial cluster

\begin{tabular}{c|c|c}
\hline Region & Major automobile industry & Joint partner \\
\hline \hline \multirow{3}{*}{ Northeast } & FAW Volkswagen, & \\
& $\begin{array}{c}\text { HuaChen Automobile, } \\
\text { Huachen BMW, JinbeiGM, } \\
\text { ZhongxingAutomobile, Jilin } \\
\text { Tongtian }\end{array}$ & Volkswagen, GM, BMW \\
& \begin{tabular}{c} 
The \\
\hline
\end{tabular}
\end{tabular}

Source: Author's research. 


\subsection{Growth strategy for the North east region's automobile industry}

The Changchun Economic-Technological Development Area, the most important core for economic development in Changchun, is planning to expand its automobile industrial area as a national base for special featured cars in the future.

As a concrete plan, the South region plans to promote investment in an automobile components industrial complex, and the North region, in a special featured car assembly and production complex. The strategy to promote the region as a major international components base in China and as a global purchasing hub through reinforcement of the automobile components industry will strengthen this area. There are also plans to develop special featured carson a world class scale and to build a special featured car complex to spur a renaissance in the Chinese automobile industry.

The special featured car and components industry in the Changchun EconomicTechnological Development Area has already reached a scale and level of performance as a result of the cluster effect. Production output from special featured cars and components increased from 240million yuan in 1995 to 43,500 million yuan in 2007 , showing a $54.2 \%$ annual growth rate.

Current special featured car production companies, FAW special featured cars, FAW bus, Hengli special featured cars, Zhongxing automotive, and Changchun Guofu, are producing 341 types of special featured cars. 83 world-famous automobile component production enterprises, including Changchun Fuao-zhangshen automatic control systems, FAW-Toyota(Changchun) engine, ZF FAWER chassis technology(Changchun), Ximenzi VDO(Changchun), Changchun automobile, and Changchun HELLA automobile, are current residents of this region and are producing thousands of automobile components.

The automobile industry in the Changchun Economic-Technological Development Area has plans for exceeding production output of 57.5 billion yuan in 2013 and 90 billion yuan by 2020 by promoting the Changchun Economic-Technological Development Area as an important international components purchasing base. If this plan is successful, the automobile components industry and special featured car industry in this area will exceed 100 billion yuan in 2020. The Changchun Economic-Technological Development Area will expand related industries by attracting automobile enterprises and by building a special featured car complex. The way that the'project-industry chain-industry group-industry complex development committee will do this is still being contemplated. The Changchun Economic-Technological Development Area is also looking for a development plan which will differentiate it from FAW automobile, but will also allow group development through a special featured complex which will be built jointly by the components industry under the lead company. The area has also suggested a detailed promotion plan with the goal of 
supplying more than $10 \%$ of components to the world automobile production market within a decade. This plan will increase the area's market position by reinforcing market competitiveness through expansion and research while creating development improvement. The Changchun Economic-Technological Development Area is planning to take four steps to help increase its competitiveness in the automobile component industry: firstly, promoting the automobile electronics industry; secondly, promoting special featured car component enterprises; thirdly, developing a product export strategy; and finally, promoting independent innovation and cyclical economy development.

China's Affair Office Development Research Center Ministry of Industry Yang, Jian-long Vice Minister stated "Now the special featured car and automobile component industry of Changchun Economic-Technological Development Area is entering a mature stage. From now on, development of the automobile industry inside the development area should be promoted by expanding the internationalization of enterprises, production platforms, information exchange platforms, special featured international trade platforms, technology support systems, investment loan support systems, human resources systems, etc., through restructuring." This highlights the Chinese government's will to promote the Northeast region's automobile industry cluster.

\section{Empirical analysis}

This research collected data and performed empirical analysis to evaluate the regional competitiveness of China's Northeast automobile cluster.

Because elements for evaluating the competitiveness of automobile clusters are abstract, the hierarchy is divided into three elements and the competitiveness evaluation system is composed of 11 elements. 


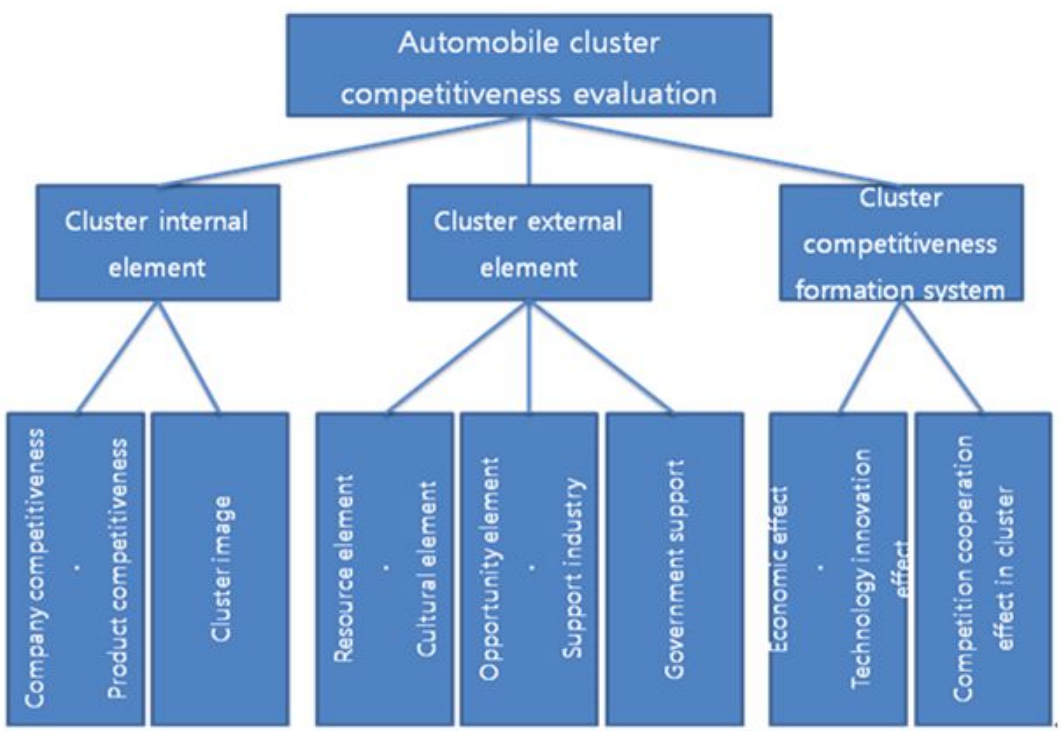

Figure 2.

Hierarchy structure for competitiveness evaluation of the Chinese automobile cluster

As a measurement method, a pair-wise comparison using a 1-9 point scale for 20 automobile-related professional elements was used. The intent was to use the 1-9 point scale as a way to measure element degrees, such as "very good, good, normal, bad and very bad."

This research established three high-ranking evaluation elements(indexes) for the Chinese automobile cluster competitiveness elements; these are: cluster internal elements, external elements, and competition cooperation effects in the cluster. It is based on the synthetic thought that cluster competitiveness is not dependent on a certain element, but depends on the interaction of the competitiveness elements.

Above all, the cluster internal element contains company competitiveness residents in a cluster and product competitiveness produced in a cluster. Image competitiveness was also expected to be important because when a cluster has a good image, leading companies want to reside there and encourage related companies to locate there. As a result, the improvement of cluster competitiveness can be expected. Likewise, the degree of labor productivity and equipment development with in the completion of car and components companies among elements affecting the automobile cluster competitiveness was established and was divided into completion car market shares, sales networks, and market response with a view on product competitiveness. At last, cluster awareness and favorable image were established in terms of cluster image competitiveness. 
Another element used to evaluate cluster competitiveness is the effect of external elements. An external element's effects are divided into resource elements, cultural elements, and governmental support. As a subordinate element of the resource element, there is cluster infrastructure, administration resources, environmental and technology resources, and workforce administ ration with in a cluster. External effects are subordinate to cultural elements because only an applied company native to the culture could survive for a long time. Another subordinate element is the opportunity element which contains market scale and economic levels of that cluster region and changes according to the consumption concepts of the consumers. The last subordinate element of the cluster external element for evaluating cluster competitiveness is government political and public service support.

Competition cooperation effects in a cluster have an economic effect, a technology innovation effect, and an internal competition cooperation effect as subordinates. Economic effects include economies of scale and economies of scope have an effect on subordinates technology innovation effects include technology innovation systems within a cluster, research and development (R\&D) investment commitments of resident companies, the development abilities of completion cars, and components as subordinates. Competition cooperation effects in a cluster consist of cooperation between contractors and subcontractors. For a better understanding of these elements, please refer to Table 3.

\section{Table 3.}

The Chinese automobile industries cluster evaluation system

\begin{tabular}{|c|c|c|}
\hline Hierarchy 1 & Hierarchy 2 & Hierarchy 3 \\
\hline \multirow{7}{*}{$\begin{array}{c}\text { Cluster } \\
\text { internal } \\
\text { element }\left(A_{1}\right)\end{array}$} & \multirow{2}{*}{$\begin{array}{c}\text { Company } \\
\text { competitiveness } \\
\left(A_{11}\right)\end{array}$} & $\begin{array}{l}\text { Degree of labor productivity for completed cars } \\
\text { and component companies }\left(A_{111}\right)\end{array}$ \\
\hline & & $\begin{array}{l}\text { Degree of equipment development for completed } \\
\text { cars and component companies }\left(A_{112}\right)\end{array}$ \\
\hline & \multirow{3}{*}{$\begin{array}{c}\text { Product } \\
\text { competitiveness } \\
\left(A_{12}\right)\end{array}$} & Completed car market $\operatorname{share}\left(A_{121}\right)$ \\
\hline & & Completed car sales network $\left(A_{122}\right)$ \\
\hline & & Completed car market responsiveness $\left(A_{123}\right)$ \\
\hline & \multirow{2}{*}{$\begin{array}{c}\text { Cluster image } \\
\text { competitiveness } \\
\left(A_{13}\right)\end{array}$} & Cluster awareness $\left(A_{131}\right)$ \\
\hline & & Cluster favorable image $\left(A_{132}\right)$ \\
\hline
\end{tabular}




\begin{tabular}{|c|c|c|}
\hline Hierarchy 1 & Hierarchy 2 & Hierarchy 3 \\
\hline \multirow{14}{*}{$\begin{array}{c}\text { Cluster } \\
\text { external } \\
\text { element }\left(A_{2}\right)\end{array}$} & \multirow{4}{*}{$\begin{array}{c}\text { Resource } \\
\text { element }\left(A_{21}\right)\end{array}$} & Cluster infrastructure $\left(A_{211}\right)$ \\
\hline & & Administration resources $\left(A_{212}\right)$ \\
\hline & & $\begin{array}{l}\text { Technology and administration workforce within } \\
\text { clusters }\left(A_{213}\right)\end{array}$ \\
\hline & & Cluster resource environment $\left(A_{214}\right)$ \\
\hline & \multirow{3}{*}{$\begin{array}{c}\text { Cultural } \\
\text { element }\left(A_{22}\right)\end{array}$} & Traditional culture within cluster regions $\left(A_{221}\right)$ \\
\hline & & Social capital within cluster regions $\left(A_{222}\right)$ \\
\hline & & Network relationships within cluster regions $\left(A_{223}\right)$ \\
\hline & \multirow{3}{*}{$\begin{array}{l}\text { Opportunity } \\
\text { element }\left(A_{23}\right)\end{array}$} & Regional automobile market $\operatorname{scale}\left(A_{231}\right)$ \\
\hline & & Economic development level $\left(A_{232}\right)$ \\
\hline & & Change of consumption concept $\left(A_{233}\right)$ \\
\hline & \multirow{2}{*}{$\begin{array}{c}\text { Support } \\
\text { industry }\left(A_{24}\right)\end{array}$} & Development degree of related industry $\left(A_{241}\right)$ \\
\hline & & Public service levels $\left(A_{242}\right)$ \\
\hline & \multirow{2}{*}{$\begin{array}{l}\text { Government } \\
\operatorname{support}\left(A_{25}\right)\end{array}$} & Policy environment $\left(A_{251}\right)$ \\
\hline & & System innovation ability $\left(A_{252}\right)$ \\
\hline \multirow{7}{*}{$\begin{array}{l}\text { Competition } \\
\text { cooperation } \\
\text { effect in } \\
\text { cluster }\left(A_{3}\right)\end{array}$} & \multirow{2}{*}{$\begin{array}{l}\text { Economic } \\
\operatorname{effect}\left(A_{31}\right)\end{array}$} & Cluster economies of scale effects $\left(A_{311}\right)$ \\
\hline & & Cluster economies of scope effects $\left(A_{312}\right)$ \\
\hline & \multirow{3}{*}{$\begin{array}{l}\text { Technology } \\
\text { innovation } \\
\operatorname{effect}\left(A_{32}\right)\end{array}$} & Cluster technology innovation systems $\left(A_{321}\right)$ \\
\hline & & $\mathrm{R} \& \mathrm{D}$ investment commitment $\left(A_{322}\right)$ \\
\hline & & $\begin{array}{l}\text { development ability of completed car, } \\
\text { components }\left(A_{323}\right)\end{array}$ \\
\hline & \multirow{2}{*}{$\begin{array}{l}\text { Internal } \\
\text { competition } \\
\text { cooperation } \\
\text { effect }\left(A_{33}\right)\end{array}$} & $\begin{array}{c}\text { Network stability degree within the automobile } \\
\text { industry }\left(A_{331}\right)\end{array}$ \\
\hline & & $\begin{array}{l}\text { Cooperation between contractors and } \\
\text { subcontractors }\left(A_{332}\right)\end{array}$ \\
\hline
\end{tabular}




\subsection{Analysis results}

Weight analysis results for the three elements (cluster internal element, cluster external element, internal competition cooperation effects in a cluster) in hierarchy laffecting the competitiveness of the Chinese automobile industry cluster is presented in Table 4. According to the results of this analysis, cluster internal elements presented a relatively high importance at $64.8 \%$. The luster external elements effect was at 23\%, economic effects, technology innovation effects, and internal competition cooperation effects also played a significant role. Cluster external elements were less important.

\section{Table 4.}

A pair-wise comparison matrix relating to the competitiveness of the automobile cluster in hierarchy 1

\begin{tabular}{c|c|c|c|c}
\hline Hierarchy 1 & A & B & C & $\begin{array}{c}\text { Relative } \\
\text { importance }\end{array}$ \\
\hline \hline $\begin{array}{c}\text { Cluster } \\
\text { internal } \\
\text { elements }\end{array}$ & 1 & 5 & 3 & 0.648 \\
\hline $\begin{array}{c}\text { Cluster } \\
\text { external } \\
\text { elements }\end{array}$ & $1 / 5$ & 1 & $1 / 2$ & 0.122 \\
\hline $\begin{array}{c}\text { Competition } \\
\text { cooperation } \\
\text { effects in } \\
\text { acluster }\end{array}$ & $1 / 3$ & 2 & 1 & 0.230 \\
\hline
\end{tabular}

1) The subordinate element weight of a cluster's internal elements

The subordinate element of a cluster's internal element(hierarchy 2) consists of company competitiveness, industry competitiveness, and cluster image competitiveness and is composed of seven subordinates(hierarchy 3). Analysis results are presented in Table 5. In the case of cluster internal elements, which showed the highest weight $(0.648)$ with in hierarchy 1 , the degree of labor productivity of completed cars and component companies, and the cluster's favorable image were shown as the most important elements in cluster competitiveness and had the highest weight $(0.750)$. Effects of the completed car market response(0.105), completed car sales network(0.258), degree of equipment development for completed cars and component companies(0.250) regarding cluster competition were observed to be less important than the completion of the car market share(0.637). 


\section{Table 5.}

Subordinate elements weight in on the a spects of cluster competitiveness

\begin{tabular}{|c|c|c|c|c|}
\hline Hierarchy 1 & Hierarchy 2 & weight & Hierarchy 3 & weight \\
\hline \multirow{7}{*}{$\begin{array}{l}\text { Cluster } \\
\text { internal } \\
\text { elements } \\
(0.648)\end{array}$} & \multirow{2}{*}{$\begin{array}{l}\text { Company } \\
\text { competitiveness } \\
\left(A_{11}\right)\end{array}$} & \multirow{2}{*}{0.731} & $\begin{array}{l}\text { Degree of labor productivity } \\
\text { for completed cars and } \\
\text { component companies }\left(A_{111}\right)\end{array}$ & 0.750 \\
\hline & & & $\begin{array}{l}\text { Degree of equipment } \\
\text { development for completed } \\
\text { cars and component } \\
\text { companies }\left(A_{112}\right)\end{array}$ & 0.250 \\
\hline & \multirow{3}{*}{$\begin{array}{l}\text { Product } \\
\text { competitiveness } \\
\left(A_{12}\right)\end{array}$} & \multirow{3}{*}{0.188} & $\begin{array}{l}\text { completed car market share } \\
\left(A_{121}\right)\end{array}$ & 0.637 \\
\hline & & & $\begin{array}{l}\text { completed car sales network } \\
\left(A_{122}\right)\end{array}$ & 0.258 \\
\hline & & & $\begin{array}{l}\text { completed car market } \\
\text { response }\left(A_{123}\right)\end{array}$ & 0.105 \\
\hline & \multirow{2}{*}{$\begin{array}{l}\text { Cluster image } \\
\text { competitiveness } \\
\qquad\left(A_{13}\right)\end{array}$} & \multirow{2}{*}{0.081} & Cluster awareness $\left(A_{131}\right)$ & 0.250 \\
\hline & & & Cluster favorable image $\left(A_{132}\right)$ & 0.750 \\
\hline
\end{tabular}

2) Subordinate element weight of cluster external elements.

Subordinate elements of cluster external elements (hierarchy 2) consist of resource elements, cultural elements, opportunity elements, support industries, and government support which is composed of 14 subordinates (hierarchy 3). Analysis results are presented in Table 6. Government support (0.419)has the highest effect of the cluster external effects. Among government support, policy environment elements (0.750) is the most important.

Cultural elements (0.048), which were expected to have a significant influence on cluster external element effects, showed a relatively low value.

Meanwhile, technology and administration workforce in a cluster (0.072) and regional automotive market scale $(0.105)$ were found to not have much of an effect on a cluster's external element effect. 


\section{Table 6.}

Subordinate element weight of cluster external element effects

\begin{tabular}{|c|c|c|c|c|}
\hline Hierarchy 1 & Hierarchy 2 & weight & Hierarchy 3 & weight \\
\hline \multirow{14}{*}{$\begin{array}{c}\text { Cluster } \\
\text { external } \\
\text { elements }\left(A_{2}\right)\end{array}$} & \multirow{4}{*}{$\begin{array}{c}\text { Resource } \\
\text { elements }\left(A_{21}\right)\end{array}$} & \multirow{4}{*}{0.267} & Cluster infrastructure $\left(A_{211}\right)$ & 0.552 \\
\hline & & & Administration resources $\left(A_{212}\right)$ & 0.236 \\
\hline & & & $\begin{array}{l}\text { Technology and administration } \\
\text { workforce in clusters }\left(A_{213}\right)\end{array}$ & 0.072 \\
\hline & & & $\begin{array}{l}\text { Cluster resource environment } \\
\left(A_{214}\right)\end{array}$ & 0.140 \\
\hline & \multirow{3}{*}{$\begin{array}{c}\text { Cultural } \\
\text { elements }\left(A_{22}\right)\end{array}$} & \multirow{3}{*}{0.048} & $\begin{array}{l}\text { Traditional culture within a } \\
\text { cluster region }\left(A_{221}\right)\end{array}$ & 0.540 \\
\hline & & & $\begin{array}{l}\text { Social capital within a cluster } \\
\text { region }\left(A_{222}\right)\end{array}$ & 0.163 \\
\hline & & & $\begin{array}{l}\text { Network relationship within a } \\
\text { cluster region }\left(A_{223}\right)\end{array}$ & 0.297 \\
\hline & \multirow{3}{*}{$\begin{array}{l}\text { Opportunity } \\
\text { elements }\left(A_{23}\right)\end{array}$} & \multirow{3}{*}{0.102} & $\begin{array}{l}\text { Regional automobile market } \\
\text { scale }\left(A_{231}\right)\end{array}$ & 0.105 \\
\hline & & & $\begin{array}{c}\text { Economic development level } \\
\left(A_{232}\right)\end{array}$ & 0.637 \\
\hline & & & $\begin{array}{l}\text { Change of consumption } \\
\text { concept }\left(A_{233}\right)\end{array}$ & 0.258 \\
\hline & \multirow{2}{*}{$\begin{array}{l}\text { Support within } \\
\text { an industry } \\
\left(A_{24}\right)\end{array}$} & \multirow[t]{2}{*}{0.164} & $\begin{array}{l}\text { Development degree of related } \\
\text { industries }\left(A_{241}\right)\end{array}$ & 0.750 \\
\hline & & & Public service levels $\left(A_{242}\right)$ & 0.250 \\
\hline & \multirow{2}{*}{$\begin{array}{l}\text { Government } \\
\operatorname{support}\left(A_{25}\right)\end{array}$} & \multirow[b]{2}{*}{0.419} & Policy environment $\left(A_{251}\right)$ & 0.750 \\
\hline & & & $\begin{array}{l}\text { System innovation ability } \\
\left(A_{252}\right)\end{array}$ & 0.250 \\
\hline
\end{tabular}

3) Subordinate element weight of competition cooperation effects in a cluster.

The subordinate element of competition cooperation effects in a cluster (hierarchy 2) consists of economic effects, technology innovation effects, and internal competition cooperation effects and is also composed of seven subordinates (hierarchy 3 ). The analysis results are shown in Table7. 
According to the analysis results, cooperation between contractors and subcontractors (0.750) received a relatively high rating as an important element in the competitiveness evaluation. R\&D investment commitment also received a relatively high rating, which has various implications. The cluster environment is important, but an even more important thing in judging competitiveness is the efforts which are made with regards to future development.

\section{Table 7.}

Subordinate element weight of competition cooperation effects in a cluster

\begin{tabular}{|c|c|c|c|c|}
\hline Hierarchy 1 & Hierarchy 2 & weight & Hierarchy 3 & weight \\
\hline \multirow{7}{*}{$\begin{array}{l}\text { Competition } \\
\text { cooperation } \\
\text { effects in a } \\
\text { cluster }\left(A_{3}\right)\end{array}$} & \multirow{2}{*}{$\begin{array}{l}\text { Economic } \\
\operatorname{effect}\left(A_{31}\right)\end{array}$} & \multirow{2}{*}{0.143} & $\begin{array}{l}\text { Cluster economies of scale } \\
\text { effects }\left(A_{311}\right)\end{array}$ & 0.500 \\
\hline & & & $\begin{array}{l}\text { Cluster economies of scope } \\
\text { effects }\left(A_{312}\right)\end{array}$ & 0.500 \\
\hline & \multirow{3}{*}{$\begin{array}{l}\text { Technology } \\
\text { innovation } \\
\text { effects }\left(A_{32}\right)\end{array}$} & \multirow{3}{*}{0.714} & $\begin{array}{c}\text { Cluster technology innovation } \\
\text { system }\left(A_{321}\right)\end{array}$ & 0.258 \\
\hline & & & $\begin{array}{l}\mathrm{R} \& \mathrm{D} \text { investment commitment } \\
\left(A_{322}\right)\end{array}$ & 0.637 \\
\hline & & & $\begin{array}{c}\text { development ability of } \\
\text { completed cars, component } \\
\text { companies }\left(A_{323}\right)\end{array}$ & 0.105 \\
\hline & \multirow{2}{*}{$\begin{array}{l}\text { Internal } \\
\text { competition } \\
\text { cooperation } \\
\text { effects }\left(A_{33}\right)\end{array}$} & \multirow{2}{*}{0.143} & $\begin{array}{c}\text { Network stability degree } \\
\text { withintheautomobile industry } \\
\left(A_{331}\right)\end{array}$ & 0.250 \\
\hline & & & $\begin{array}{c}\text { Cooperation between } \\
\text { contractors and subcontractors } \\
\left(A_{332}\right)\end{array}$ & 0.750 \\
\hline
\end{tabular}

\section{Conclusion}

This research has the objective of finding the competitive decision making elements with in the Chinese automobile industry clusters in order to help provide meaningful information for Korean automobile companies entering China. This research examined a cluster's internal elements, a cluster's external elements, and the competitive cooperation effects in a cluster as the three cluster competitiveness elements, then set 11 indexes under 
these three elements and again set 28 subcontractors through the AHP analysis. This research also analyzed which elements are currently meaningful in influencing the Chinese automobile industries cluster competitiveness. A summary of this research is presented below.

Firstly, among the three elements deciding cluster competitiveness, cluster internal elements (64.8\%) was analyzed to have the greatest effect on cluster competitiveness. Secondly, among the 11 subordinate elements, company competitiveness, product competitiveness, cluster image competitiveness, resource elements, cultural elements, opportunity elements, industry support, government support, economic effects, technology innovation effects, internal competition and cooperation effects, company competitiveness (0.731), and technology innovation effects (0.714) showed a high level of importance. Thirdly, among the lowest 28 subcontractors, cooperation between contractors and subcontractors and the policy environment $(0.750)$ were analyzed as being significantly important.

A realistic implication of this research is that because the competitiveness of an automobile industry cluster depends on the competitiveness of the resident companies, attracting companies that possess competitive products and R\&D investment commitment are needed in order for the Chinese Government to secure increased cluster competitiveness.

In the case of companies based on product technology competitiveness, from the standpoint of the Korean automobile companies, pioneering local markets and entering China as a global sourcing base are thought to be possible if companies understand the Chinese governmental promotion strategy and enter under positive conditions.

The purpose of this research has an exploratory characteristic which focuses on the total competitiveness element of the Chinese automobile industry clusters, especially the Changchun Economic \& Technological Development Zones, the primary city of the Northeast region, and establishing the importance of these elements and their effects on cluster competitiveness. However, I should add that this research has limitations in terms of research methodology. This research used the analytical hierarchy method, statistically processed the surveys of specialists, and focused on the importance between cluster competitiveness and the elements which affect them. Therefore, generalizing the importance of cluster elements throughout all Chinese automobile industry clusters has severe limitations. A case study which reflects the local characteristics and takes causal inference into account is currently needed.

A more realistic result could also be obtained by measuring the competitiveness of each region by scale, and by its level of technology through more regional cluster samples (sample group) which take into account the above-stated problems and limitations. 


\section{Acknowledgements}

This work was supported by the Korea Research Foundation Grant which is funded by the Korean government(MOEHRD)(KRF-2008-005-J01601).

\section{References}

Porter, Michael E, ON COMPETITION, Seoul:Sejong Research Institution, 2003.

Kim yeounseong and others, Service Administration, Seoul:Beobmoonsa, 2004

Kim yeounseong and others, Innovative strategy administration quality of super company, Seoul:Cheongmoongak, 2006

Lee kyunghwan, Country survival strategy, Seoul:Doonam, 2001

Jeon jaewan · Kim hyunggi, Research on building logistics cluster element, business administration researches, Inha university Administration Research Institution, 2008

Kim jeonghong, Innovation strategy reinforcement way of regional industry: with regional innovation policy as a center, Korea Institute for Industrial Economics \& Trade, research report, No.488, 2004

Bock deukgyu, Review on cluster concept, Trends and Prospect, No.57, pp114-141, 2002.

Lee youngsook, Critical reexamination on regional innovative system: regional innovative system for what, for whom?, Trends and Prospect, No.59, pp141-182, 2003

Seo joonghae and others, National Science and Technology System-Vision and Policy Challenge, Korea Development Institute, 2002

Jeong myonggi, Chinese Silicon Valley:Zhongguancun, Industrial Location, No.12, pp30-34, 2002

Jeong seonyang,Way of Building Regional Innovation System Scientific Technology Policy, 3/4, pp79-98, 1999

Jo young chan, obstacles that China has to over to be an economic power, Daeshin Economic Research, 2005

Gang seung ho, Comparison on competitiveness of Northeast main cities, Northeast Asia Economic Research, Vol.20, No.1, pp1-23. 2008

Kim Seong ho, A study on strategic clustering for the internationalization of regional economic development, International Administration Review, Vol.9, No.1, pp129-149, 2005

Kim sooyeoup, Lee sung woo, Kim chan ho, Song joo mi, Research on growth strategy of global leader logistics company, Korea Maritime Institute, 2009 
Kim jeong ho, Researches:Potential Ways to Develop the Regional Agriculture Cluster, Korean journal of Agricultural Management and Policy, Vol.31, No.3, pp514-534, 2004

Yoo Jaehong Om Kiyoung · Kim Byung-geun · Kim Kwanyoung · Lee Jungmann, A strategic Framework for Attracting R\&D Center of Foreign Companies and Its Implications for IT Industry, Journal of Korea Technology Innovation Society, Vol.10, No.4 pp255-283, 2007

Lee sung woo - Song joo mi, Comparative Study of Global Competitiveness of the Port , Korea Maritime Institute, 2009

Lee jae sung, A Comparative Study of Local Government Capacity: Local Government in Chungcheongnam-do, Journal of Korean Association for Policy Sciences, Vol.11, No.3, pp27-48, 2007

Lee jong yeol $\cdot$ Chae won ho $\cdot$ Lee chang won $\cdot$ Son ho joong, Development ways of Korea Innovative Cluster : With Priority Analysis on Success Element of Industrial Complex Cluster as a Center, Journal of Korea Association for Policy Analysis and Evaluation, Vol.12, No.5, pp165-189, 2005

Lee Jun yeop, Ha Hun goo, Analysis on logistics competitiveness of Chinese main cities, Contemporary China Research, Vol.9, No.1, pp139-170, 2007

Yim Haksoon, Developing the Framework for Evaluating Regional Cultural Industry Clusters, Korea Society and Administration Research, Vol.15, No.2, pp305- 324, 2004

Cho Dae-Woo Jin ZhengHao, Effects of Environmental Factors of Innovative Clusters on the Performance of Venture Firms in China, International Administration Review, Vol.12, No.1, pp93-118, 2008

Jo Hyung je, A Spatial Change of R\&D Function in Auto Suppliers Located in Ulsan , Korea Society, Vol.40, No.5, pp207-232. 2006

Jo Hyung je, Region and Regional Policy Rediscovered: A Modeling for Regional Development in Ulsan , 2005

Joo sue hyun - Lee sun young, Machinery Components Industry's Cluster Effectiveness Analysis of Busan, Economic Researches, Vol.22, No.4, pp201-226, 2004

Choi Baek-Ryul, Kong Hyeong-Seog, Kim Suk-Jin, Strategies for Development of Automobile Industry in Korea According to Market Openness of China: Focusing on Firms located in Jeollabukdo, International Administration Review, Vol.9, No.1, pp173-198, 2005

Choi Sang Ho ,Choi Hung Kyu, Lee Min Soo, Choi Young Chan, Development stage strategy of Regional based Agricultural Cluster though Multi Disciplinary Approach, Rural plan, Vol.11, No.4, pp33-45, 2005 
Choi young jin, Potential and Restriction of Shanghai Automobile Industry Innovative Cluster, Journal of Korea Social Institute, pp67-68, 2006

Aberdeen Group, Supply Chain inventory strategies benchmark report, Boston, Massachusetts, 2004

Harland C., The Dynamics of customer Dissatisfaction in Supply chains, Production Planning and control, Vol.6, 995, pp.209 217

Lawrence, F. B., Calculating pricing optimization, Industrial Distribution, Vol.95, pp.26 27, 2006

Schreibfeder, J., Achieving Effective inventory management, 3rd Edition. Alexander Communications Group Inc, New-York, 2005

Huang, C., Lin, W., Wang, S. \& Wang, W. (2009). Planning of educational training courses by data mining: Using China Motor Corporation as an example. Expert SystAppl, 36(3, Part 2), 7199-7209.

黄火灵，产业集群与我国的汽车产业，北京汽车，2004

张丽莉，丰田汽车产业集群的发展及启示，汽车工业研究，2005

朱华晟，浙江产业群，浙江大学出版社，2003

苏江明，产业集群生态相研究，复旦大学，2004

左学金，长江三角洲城市群发展研究，上海:学林出版社，2006

千庆兰，中国地区制造业竞争力新论，北京:科学出版社，2006

高 建，中国企业技术创新分析，清华大学出版社，1997

顾朝林等，中国高新技术产业与园区，中心出版社，1999

夏海钧，中国高新区发展之路，中心出版社，2001 
